\title{
Performance of polyurethane grouting to handle heavy seepage in tunnels
}

\author{
N Rana and R Nair \\ Heavy Civil Infrastructure, L\&T Construction \\ Chennai, India \\ ns-rana@Intecc.com
}

\begin{abstract}
Fault zones, shear bands, underground water channels and other features in the Himalayan geology have made tunneling a very complex activity in the region. The major hydropower projects present construction problems but also render the project economically tough to handle. A case study is presented in this paper wherein heavy ingress of water in one of the tunnels is document. This problem has caused lot of disruptions and serious concern on feasibility of the project. One of the attempts of using polyurethane grout has been discussed and its implementation at the site is presented. Grouting is considered to be the most common defense towards water ingress in tunnel. Polyurethane grouting is a grouting technique that involves the injection of expanding polyurethane to cutoff water flow through joints or cracks or to fill voids beneath or behind subsurface of excavated area. The grout is injected with high pressure through a predrilled hole, grout then expands to fill the crack or void. Polyurethane grouts used for both leak sealing structures against high water flow and ground consolidation. The project in consideration is construction of head race tunnel (HRT) in TapovanVishnugad Hydro Electric Power Project (520 MW), Uttarakhand, India. The heavy ingress of water encountered with the high rate of seepage (1500 to $1800 \mathrm{l} / \mathrm{min}$.) caused erosion and dissolution, resulting in collapse of the opening. Polyurethane grout was used to start remedial measure in order to stabilize the rockmass and to divert the excessive water seepage. In this paper discusses the challenges during remedial measures and stabilization, implementation approach and steps to handle heavy seepage using Polyurethane grout in the tunnel are described.
\end{abstract}

Keywords-polyurethane grout; head race tunnel; hydrogeology

\section{INTRODUCTION}

Tunnels in Himalayan region encounter significant hazards due to the geological and hydrogeological uncertainty. During construction, modifications and adaptations of these structures in the design are common. Likewise, persistent, time- consuming and expensive remedial works during the construction of the underground structures are no exception. The most common hazard is influence of groundwater which can be consequence of poor geology of the area. Despite extensive investigations, the water flow under the ground is mostly unpredictable in space and time. There are incidences portraying destructive processes that may appear abruptly. Water ingress in tunnel can have catastrophic consequences to the structural integrity. Amongst the various options, groutingprovides most frequently used remedial option to improve of mechanical and sealing properties of soil and rock. This has created a demand of higher performance grouting materials, Polyurethane grouting involves the injection of expanding polyurethane to cutoff water flow through joints or cracks and to fill voids beneath or behind subsurface of excavated area. The grout is injected with high pressure through a predrilled hole, grout then expands to fill the crack or void. Polyurethane grouts used for both leak sealing structures against high water flow and ground consolidation. The paper deals with heavy ingress of water with slushes encountered after face blast during construction of Head Race Tunnel (HRT) in the TapovanVishnugad Hydro Electric Power Project, Uttarakhand India. The rate of seepage recorded at peak was 1800 to $2000 \mathrm{lit} / \mathrm{min}$. The seepage of water from excavated face caused to erosion and dissolution of material and resulted in the collapse of the opening. Polyurethane grout was attempted as a remedial measure in order to stabilize the rockmass and to divert the excessive water seepage. In this paper, the process undertaken to handle the heavy seepage from the tunnel face with slushes by using polyurethane grout, has been described along with the performance and methodology of polyurethane grout in such situation.

\section{About the Project}

The project TapovanVishnugad Hydro Electric Power Project (4 X $130 \mathrm{MW}$ ), Uttarakhand, India, is situated on river Alaknanda /Dhauliganga in the district of Chamoli about $280 \mathrm{~km}$ from the nearest railhead Rishikesh. The project is situated in latitude N 30o $29^{\prime} 30^{\prime \prime}$ ' and longitude $\mathrm{E} 79 \mathrm{o} 37^{\prime}$ '30" this zone is listed as earthquake zone number $\mathrm{V}$, this is a run-of- river project, the catchment area up to headworks is 3100 sq. $\mathrm{km}$ and the average annual rainfall $1625 \mathrm{~mm}$. the catchment of river Dhauliganga extend from $30015^{\prime} \mathrm{N}$ to $31000^{\prime} \mathrm{N}$ and longitude $79 \mathrm{o}^{\prime} 0^{\prime} \mathrm{E}$ to $80 \mathrm{o} 15^{\prime} \mathrm{E}$. It is completely mountainous, significant part of which is covered by snow (1483.00 sq.km). In the project, de-siltation chamber, head race tunnel, power house and tail race tunnel are located on the left bank. The study area was envisaged for Head Race Tunnel (HRT) which is used for conveyance of water from desilting basin to power house via surge tank 
and pressure shaft. The length of these tunnels is $11.9 \mathrm{~km}$ and $5.40 \mathrm{~m}$ in diameter. It is a horse shoe shape tunnel with design discharge and velocity of 119.2 cumecs and $4.93 \mathrm{~m} / \mathrm{s}$, respectively.

\section{GEOLOGY}

\section{A. Regional Geological Setting}

The project area falls in Dhauliganga and Alaknanda valley exposing rock mass classed as central Himalayan crystalline by Heim \&Gansser (1939). They are composed mainly of medium to high grade metamorphics. The crystalline rocks of the Dhauliganga valley derived from politic, semipelitic and psammitic sediments which occasionally are interlayered with Metabasic and to a lesser extent in DhakJarkula area calcareous rocks are also recognized. Towards the south, the crystalline are thrusted over the lesser Himalayan sediments of Garhwal group of rocks Main Central Thrust (MCT). This passes through village, Helong, located $3 \mathrm{~km}$, downstream of the power house site area. The grade of metamorphism increases northward from Helong to Joshimath and from Tapovan to Joshimath ranging from biotite near Karchi and Animath village to garnet near Tapovan and Helong to staurlite grade near Bargaon, Parsari and Jogi dhara area. These rocks gradually combine into the kyanite zone. Thus two major formations namely Tapovan and Joshimath formations are formed. In between Tapovan and Joshimath formation there is no shear plane or plane of discordance nor there any topographic break. The schistosity of the rocks is very well marked by the preferred orientation of flaky minerals like biotite, muscovite and also chlorite when present. The gneisses are characterized by the presence of the alternate bands of the leucocratic quartz, feldspathic mineral and mesocratic to milenocratic micaceous bands. The mica flaks are elongated along the foliation. The general strike of foliation is NW-SE and dips at $30 \mathrm{o}$ to $45 \mathrm{o}$ towards NE. in general the gneisses of Joshimath area dips mainly in the NE direction with considerable local variations. The rocks are well documented by several small scale folds, ptygmatic folds, and pinch and swell structures, boudinage, mineral lineation and crenulation lineation. $\mathrm{Rb} / \mathrm{Sr}$ geological dating and isotropic studies have revealed a Precambrian age with varying ratio of radioactive isotopes of strontium in the sequence (Singh, A.K). Joshimath is situated with in the zone of biotite muscovite injection gneisses which resembles certain types of Darjeeling gneisses. TapovanHelong and Joshimath formations have the great variation in the amount dip and small scale refolding in crystalline rock indicate that area has suffered polyphaser deformation (Heim \&Gansser 1939).

\section{B. Geology along the Head Race Tunnel (HRT)}

The head race tunnel of the project is $11.9 \mathrm{~km}$ long and was driven through higher Himalayan central crystalline consisting of Augen gneisses, gneisses, schists, quartzites and metabasics belonging to Tapovan and Joshimath formations with increasing grade of metamorphism from south to north. The Main Central Thrust (MCT) one of the major low angle fault zone along the Himalayan lies about $3 \mathrm{~km}$ south of power house location. The rock cover and rock type over the tunnel are shown in Fig. 1, which varies from $\pm 300 \mathrm{~m}$ up to chainage $1475 \mathrm{~m}$. Beyond which it varies gradually to $\pm 1200 \mathrm{~m}$ up to chainage $10500 \mathrm{~m}$. From chainage $10500 \mathrm{~m}$, it gradually decreases sown to $\pm 200 \mathrm{~m}$ near to surge shaft.

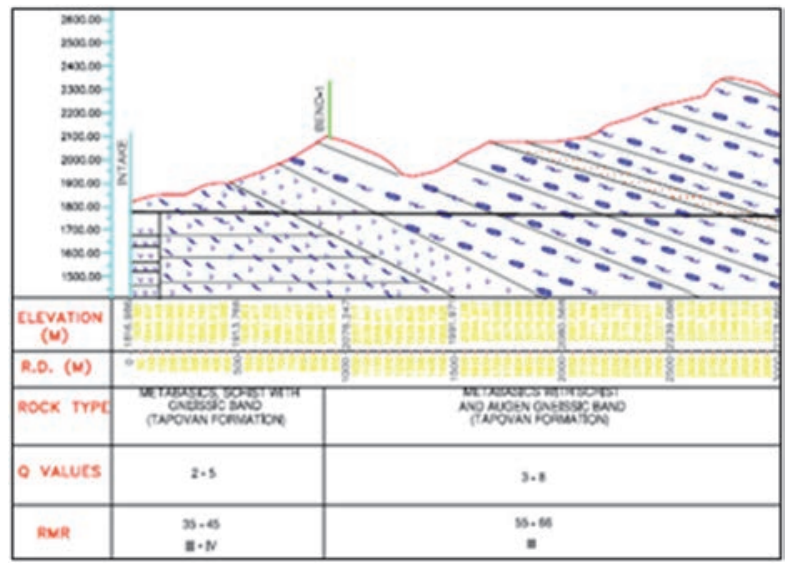

Fig. 1. Longitudinal section along head race tunnel (during initial site investigation)

In the entire length of head race tunnel excavation of project was $57 \%$ rockmass encountered falls under class III (Fair), 28\% under class IV (Poor), 7\% under class V (Very Poor) 3\% under class VI (Extremely poor) rock category as shown in the Fig. 2.

- The rocks exposed throughout the HRT mainly comprises higher Himalayan metamorphics, comprising of schists, gneisses and quartzites, metabasics affected by shearing and have undergone to mylonitization at many places due to the effect of MCT and subsidiary faults/faults.

- The rock exposed nearer to the fault/thrust planes are highly mylonitized and the degree of mylonitization decreases away from the encountered faults.

- As per the tectonically deformed / mylonitized rocks exposed on surface at places throughout the length of HRT, have also been encountered during excavation.

- Considering the geological conditions as per surface exposure and as encountered during excavation, it was expected that the sympathetic shear zones shall be encountered at many places while further tunneling.

\section{Rockmass Characteristics of the Failure Zone}

Geology of the face was slightly fractures Augen gneiss and mica schist of Tapovan formation with water seepage and shear zone (fractured and crushed rock materials with gauge and clay), moderately to highly weathered, few vertical to sub vertical joints with clay filled and fractured rock materials in between the vertical joints. Three plus random joint sets, rough or irregular, planar, crushed rock, earth like; disintegrated or crushed rock and clay zone thick enough to prevent rock wall 
contact, zone or bands of disintegrated or crushed rock and clay. The tunnel orientation $\mathrm{N} 338 \mathrm{o}$ and the main joint orientation of the face was J1/Foliation joint 40/N020o, J2 40/N220o. J3 70/N120o and Jr 70/No50o and its falling in the rock class $\mathrm{V}$ (Very Poor). Three-dimensional tunnel $\log$ of the HRT is shown in the Fig. 3 and joint properties are tabulated in Table I.

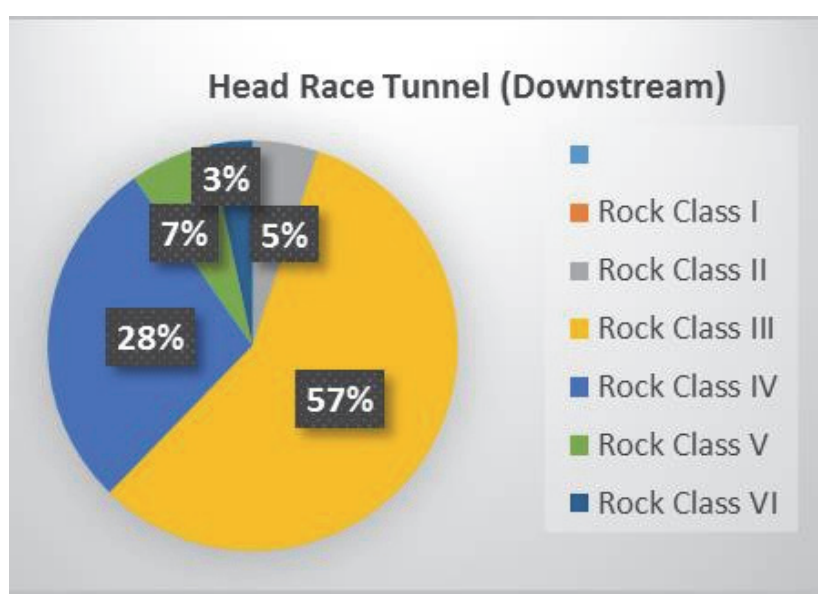

Fig. 2. Rock mass classification of head race tunnel (Ch. 0.0 to $1553 \mathrm{~m}$ )

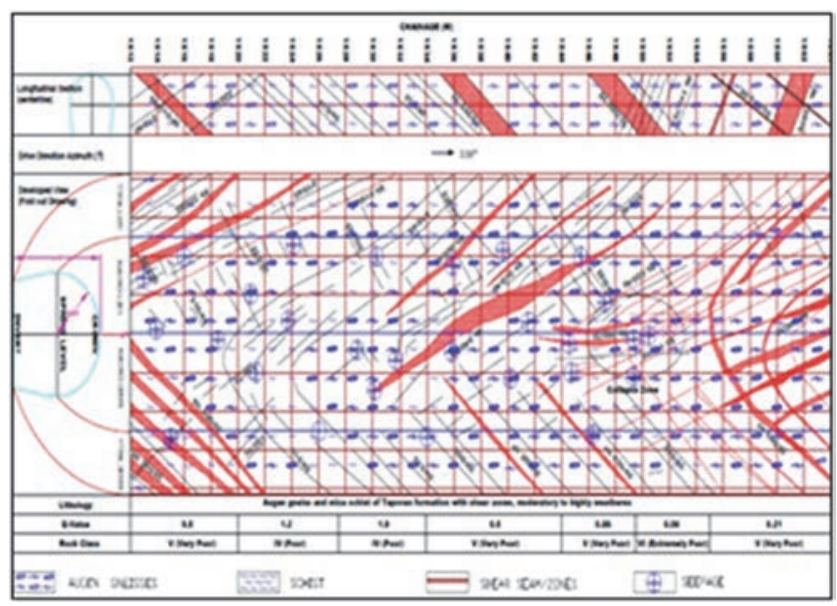

Fig. 3.Three dimensional tunnel $\log$ of the head race tunnel

TABLE I. JOINT PROPERTIES OF THE FAILURE ZONE

\begin{tabular}{|c|c|c|c|c|c|c|}
\hline $\begin{array}{c}\text { Joint } \\
\text { Orie- } \\
\text { tation }\end{array}$ & $\begin{array}{c}\text { Spacing } \\
\text { (cm) }\end{array}$ & $\begin{array}{c}\text { Rough } \\
\text {-ness }\end{array}$ & $\begin{array}{c}\text { Persis- } \\
\text { tence, } \\
\text { (m) }\end{array}$ & $\begin{array}{c}\text { Apertu } \\
\text { re } \\
\text { (mm) }\end{array}$ & Infilling & $\begin{array}{c}\text { Water } \\
\text { condition }\end{array}$ \\
\hline $40 / 355$ & $6-20$ & $\begin{array}{c}\text { Smooth, } \\
\text { Planar }\end{array}$ & $>10$ & $2.5-10$ & Clay & Flowing \\
\hline $70 / 110$ & $20-60$ & $\begin{array}{c}\text { Rough, } \\
\text { Planar }\end{array}$ & $>10$ & $0.5-2.5$ & Clay & Dripping \\
\hline $55 / 220$ & $60-200$ & $\begin{array}{c}\text { Rough, } \\
\text { Planar }\end{array}$ & $3-10$ & $0.5-2.5$ & Clay & Dripping \\
\hline $80 / 335$ & $>200$ & $\begin{array}{c}\text { Rough, } \\
\text { Planar }\end{array}$ & $1-3$ & $<0.5$ & $\begin{array}{c}\text { Clay } \\
\text { Coated }\end{array}$ & Dry \\
\hline $60 / 040$ & $60-200$ & $\begin{array}{c}\text { Slicken } \\
\text { sided, } \\
\text { Undulat }\end{array}$ & $>10$ & $10-100$ & Gauge & Dripping \\
\hline
\end{tabular}

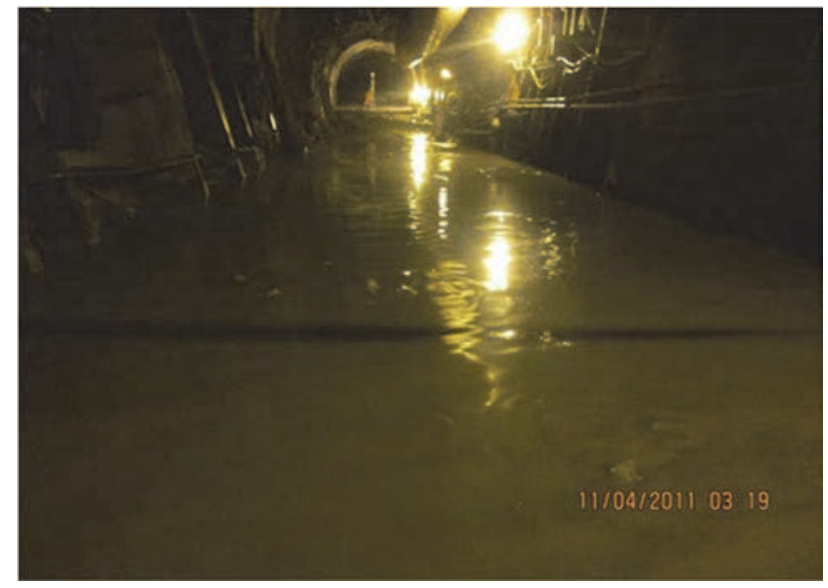

Fig. 4. Waterlogged in the head race tunnel due to heavy water ingress

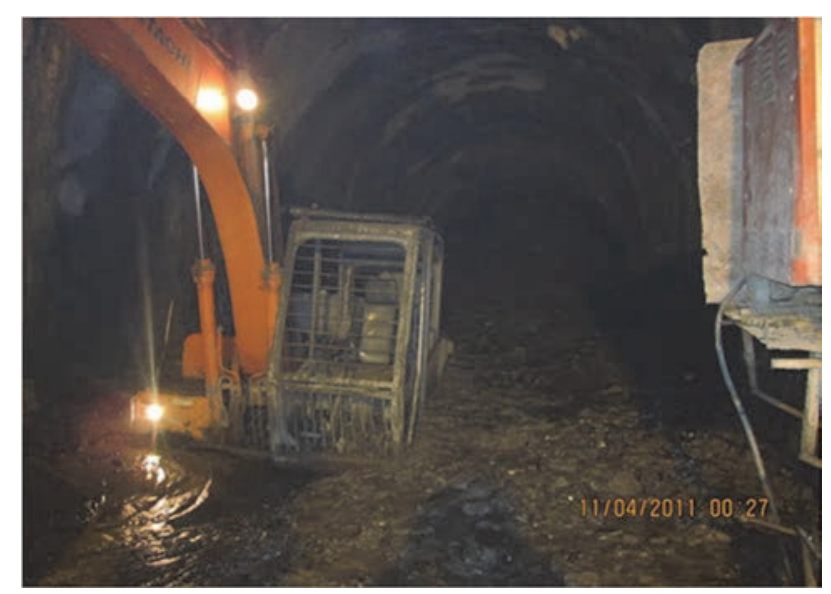

Fig. 5. Machineries and equipments stuck in the slushes

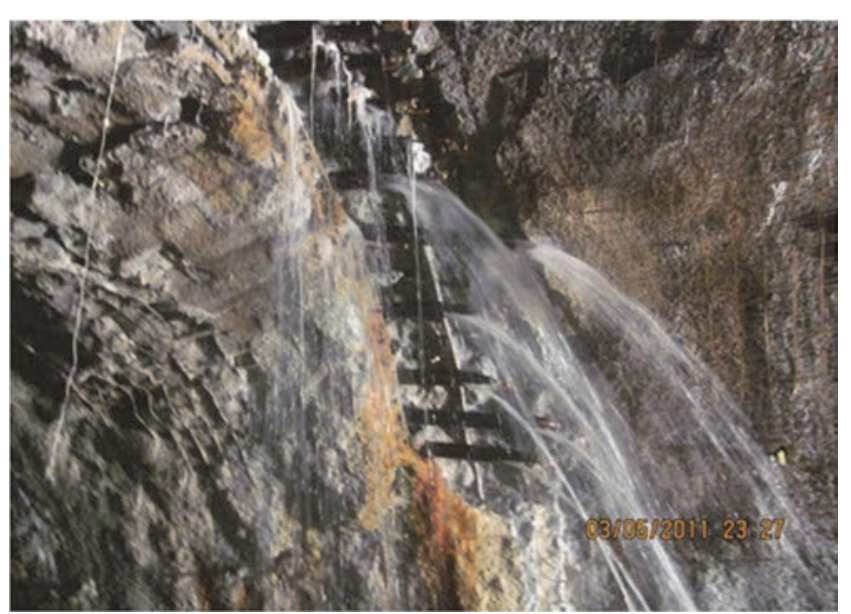

Fig. 6. Seepage water diverted from the tunnel face by using probing holes

\section{DESCRIPTION OF THE PROBLEM}

During the construction of the HRT - downstream face, there was rockfall at chainage $1553 \mathrm{~m}$. This was followed by continuous seepage of water with slushes. The rock fragments/filling from the open joints was continuouslyWashed out. finally, sudden ingress of ground 
water was encountered from the crown portion of the face, it covered a region of $75 \mathrm{~m}$ area away from the face. After few hours' ground water stabilized and flow continued at a rate of 1500 to $1800 \mathrm{Kl} /$ day. Due to this heavy slush, 4-5 lattice girder near to face has completely damaged and formed a huge cavity above the crown level at face. The entire construction work has hampered along with severe damage to machineries and pre- installed rock support as shown in Fig. 4 to 6 . Treatment of this failure zone was identified as the critical task.

\section{EXCAVATION METHOD AND ROCK SUPPORT INSTALLATION BEFORE FAILURE}

The HRT tunnel was excavated by conventional drilling and blasting. Due to poor to extremely poor rock mass condition at certain locations, the excavation sequence had heading \& benching. In case of adverse geological condition (ground flowing conditions), multiple drifting method was being adopted. Based on detailed design, the various types of rock support installed in tunnel excavation can be summarized as:

- Shotcrete (50 to $200 \mathrm{~mm}$ ) as per rock class

- Rock bolts $3.0 \mathrm{~m}$ long (1.5 to $2.5 \mathrm{c} / \mathrm{c}$ ) as per rock class

- Wire mesh (single and double layers)

- Steel ribs (300, $600 \& 900 \mathrm{~mm}$ spacing) and lattice girder in some places $(500,1000,1500,2000 \mathrm{~mm}$ spacing) as per rock class.

- Pre and post grouting

- Drainage holes

- Probe holes for forecasting of the geological and hydrogeological conditions before advancement

- For polling/Spilling (using steel rods, channels, pipes etc.).

\section{STEPS To HaNDLE HEAVy SEEPAGE AND CAVITY TREATMENT}

- Dewatering the seepage water from tunnel and then remove the muck/slush to access the treatment activity.

- Due to the heavy rock fall and seepage, cracks were observed in some places. For safe construction, the loose rock fragments were scaled and chipped. Consequently, shotcrete was sprayed to hold the loose surface rock mass for safety purpose.

- 4.0 to $8.0 \mathrm{~m}$ long self-drill anchor were installed to holding the wedges, and cement grout injected self-drill anchor for consolidation of the surrounding rock matrix of the influenced zones and to reduce the permeability of the rock masses.

- First stage, pipe roofing with $15 \mathrm{~m}$ long and $114 \mathrm{~mm}$ diameter steel pipes, above spring level of the tunnel $\left(10^{\circ}\right.$ to $15^{0}$ inclined outside) having overlap after every $10 \mathrm{~m}$. with second stage of pipe roof.

- Chemical grouting (polyurethane grout) is performed through slotted pipes (used for pipe roofing), to divert the ground water flow and fill-up the washed out joint.

- Grouting the roof and wall portion to fill up the gap between backfill concrete and surrounding rock mass.

- Drainage holes were installed to release water pressure.

- Probe holes were drilled for forecasting the geological and hydrogeological conditions before advancement.

\section{Polyurethane Grout}

\section{A. Introduction}

Polyurethane grouting is a grouting technique that involves injection of polyurethane to cutoff water flow through joints or cracks or to fill voids. The grout is injected under low pressure through a predrilled hole. The grout then expands as it comes in contact with water to fill the void. Many polyurethane grout products are available with variations in viscosity, reaction time, reaction with water, expansion characteristic and flexibility of the reacted grout. Polyurethane grouts can be single or multi-component grouts and can react when coming in contact with water or require a reactant. It is important to select the proper grout for the specific application. The technique has been also used to fill voids behind subsurface walls and seal leaking cracks and joints in subsurface structures.Polyurethane may be used to grout the water charged jointed rock masses. The PU grout stabilizes, strengthen and seal the rock mass by diverting the huge seepage water from the tunnel face to farther area. The face condition can also be improved by injecting PU grout.

\section{B. Material Description}

In this case study, TamPur 125 is used as polyurethane is employed for grouting. TamPur 125 is based on a polyol component (part A) and a polymeric MDI (part B). When mixed, hydrophobic polyurethane foam formed which is tough, rigid and resistant to a wide range of chemicals. The compound reacts rapidly to "cut off" large water leaks [1]. Polyurethane, polyol and isocyanate reacts forming a high strength adhesive material. The main property of polyurethane is its versatility, it can be found in different formulations having different properties either in liquid or in hardened phase, such as viscosity, thixotropic, foaming reaction (depending on the water being present) and mechanical strength. The properties of polyurethane compound are presented in Table II. The polyurethane chemical grout swells up to 20 times its size when it comes into contact with water and seals the rock mass. The grout has good compressive strength of $80 \mathrm{MPa}$ once it hardens, thus providing sufficient strength to loosen material in the joints Table III provides reaction time of polyurethane compounds at different temperatures. The key benefits of polyurethane grout are:

- High foam strength

- Rapid reaction

- Good bond strength

- Medium viscosity

- Solvent free, environmentally safe. 
Two-component systems can have high expansive properties with many of them capable of curing to a foam density of $6 \mathrm{lb} / \mathrm{cu} \mathrm{ft}$. Unlike the hydrophobic or hydrophilic systems, they do not require water as a catalyst as the reaction is started when Part A comes into contact with Part $\mathrm{B}$ in a static mixing tube. They are generally much faster reacting systems and can reach up to 25 times expansion in as little as 7 to 10 seconds. With the high expansion rates and extremely fast reaction times, they can have the potential to move structures and require extreme care when using.

TABLE II. PROPERTIES OF TAMPUR-125 POLYURETHANE COMPOUNDS

\begin{tabular}{|l|l|l|}
\hline \multicolumn{1}{|c|}{ Properties } & $\begin{array}{l}\text { TamPur 125 Part } \\
\text { AamPur }\end{array}$ & $\begin{array}{l}\text { Tar Part } \\
\text { R }\end{array}$ \\
\hline Colour & Opaque & Brown \\
\hline Density & 1.05 & 1.23 \\
\hline Mix ratio (A:B by volume) & $1: 1$ & $1: 1$ \\
\hline TamPur 125 mixed at a ratio of 1:1 & Brown \\
\hline Colour & 1.1 \\
\hline Density & $1 \mathrm{Day}$ \\
\hline Final cure & $300-400 \mathrm{cps}$ \\
\hline Viscosity @ 25oC & $3-4 \%$ \\
\hline Elongation at break & Up to 20 times \\
\hline Expansion & $80 \mathrm{MPa}$ \\
\hline Compressive strength confined & $2 \mathrm{MPa}$ \\
\hline Compressive strength free foam & $12.9 \mathrm{MPa}$ \\
\hline Slant shear bond strength BS6319- \\
4
\end{tabular}

TABLE III. REACTION TIME OF TAMPUR-125 POLYURETHANE COMPOUND

\begin{tabular}{|l|l|l|}
\hline \multicolumn{1}{|c|}{ Reaction time (1:1) } & \multicolumn{1}{c|}{ @ $\mathbf{1 5}^{\circ} \mathbf{C}$} & \multicolumn{1}{c|}{ @ $\mathbf{2 5}^{\circ} \mathbf{C}$} \\
\hline Cream time & $50 \mathrm{sec}$ & $30 \mathrm{sec}$ \\
\hline Gel time & $120 \mathrm{sec}$ & $90 \mathrm{sec}$ \\
\hline Take free time & $180 \mathrm{sec}$ & $150 \mathrm{sec}$ \\
\hline
\end{tabular}

A major advantage to sealing active leaking cracks/joints is that material is water activated as opposed to most materials that require the water intrusion to be eliminated before the repairs can be done. Two-component polyurethane product designed for rapid stabilization for soft ground, rapid cavity fillings and strata consolidation together with fire resistant properties. These products are used when enhanced structural integrity of the rock is required, while providing strength and flexibility [1].

\section{- Extreme water ingress}

- $\quad$ Large voids

- $\quad$ Dry fissure grouting

- Foundation stabilization

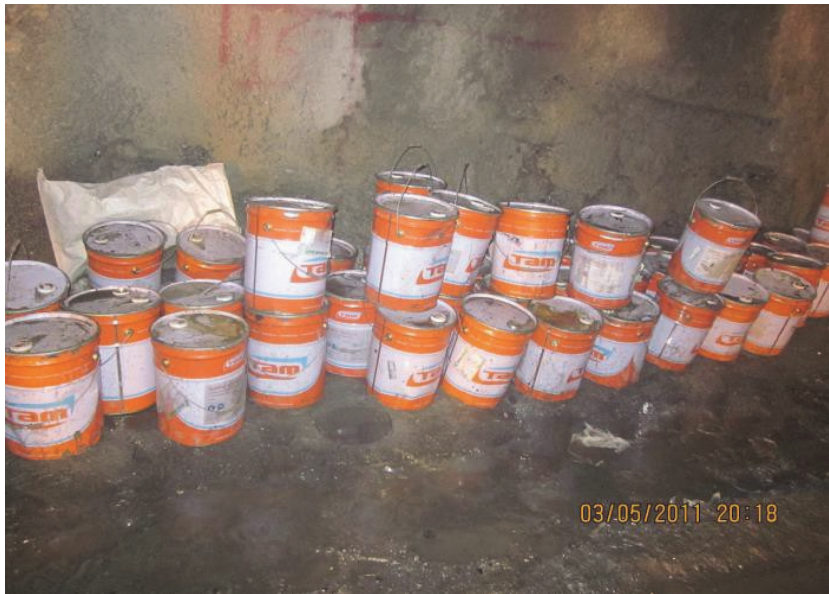

Fig. 7.Polyurethane grout materials

\section{GroutingEquipment}

Injection of grouting materials into the rock mass was performed by grouting pumps. Piston type pumps with electric or pneumatic drive were used. The grout material was technically designed to transfer the pressure of the grouting material, preventing back flow of the material out from the borehole. The pumps were equipped with a back valve. Along with pumps, grouting packers, grouting anchors or bolts, grouting tubes etc. are also employed [2].

\section{Grouting Methodology}

The HRT of TapovanVishnugad hydro power project had followed the standard industry practice of filling open joints/cavity and sealing the heavy seepage by pressure grouting using polyurethane chemical compounds.

1) Find out the seepage path and reason of failure: The first step in procedure was to identify the source of possible water carrying joints with the help of geological mapping of the excavation faces. Two sub-vertical shear planes were found to intersect in the crown portion of the failure face, one was the foliation plane $(40 / \mathrm{N} 355)$ and another shear plan (60/N040). Due to the intersection of these weak and water bearing planes in the crown portion, flooding had occured during opening the tunnel face. The water flow carried the infilling materials with water, causing collapse of the opening face. Investigation probe hole of $10.0 \mathrm{~m}$ long, $10 \mathrm{o}$ inclined upward $(10.0 \mathrm{~m}$ behind and $1.0 \mathrm{~m}$ right side crown of the collapse face) were drilled. Behind the collapse face, some drainage cum probe hole were drilled for the purpose of diverting the water channel and reduction of the water pressure.

2) Selection and drilling of first stage pipe roofing: After identification of the weakness plane, the treatment techniques were planned. It was decided to employ pipe roof to stabilize the tunnel roof ahead of face. Hence, the profile was marked on the face followed by drilling of holes for pipe roofing in the failure zone. The drill holes were $15.0 \mathrm{~m}$ long and $119 \mathrm{~mm}$ diameter, followed by insertion of steel pipes for pipe roofing. In order to control drill hole deviation, optical target has fixed in the drifter of drilling machine and surveyor continuously measured the orientation of the drilling holes. Total 24 no's of holes drilled, and average 
drilling time was $10 \mathrm{~min} / \mathrm{m}$. The pipe lengths of $3.0 \mathrm{~m}$ were coupled after inserting of previous pipe segments and simultaneously the pipes were pushed during drilling. In order to inject polyurethane grout, these pipes were perforated in different spacing on the basis of the probe hole and previous drilled holes. Geologists continuously observed and recorded the drilling behaviors, penetration rate and seepage behaviour to investigate the exact shear zone location for grouting purpose. Thus, pipe roofing was used to create an umbrella like structure around the roof and above spring level to control displacement of rock masses (Fig. 8).

3) Injection of polyurethane compound: After completion of drill holes and packer fixing, injection of polyurethane compounds was undertaken. To inject these compounds, special grout pump which was mechanically operated. The pumps had two pistons to push the compound separately. The ends of the pistons were connected to the main packer. When mixed, a hydrophobic polyurethane foam is formed within 30 to 60 second, which is tough, rigid and resistant to a wide range of chemicals, this will react rapidly to cut off large water leaks and fill water charged jointed rock masses. Injection was initiated from lowest hole of the left side spring level to crown portion and finally closed in the right side spring level. Initially, few minutes, high injection rate of 20 to $30 \mathrm{lit} / \mathrm{min}$ was maintained with low injection pressure (2-5 bar). In the case of water flow in the grout holes, grout pressure was increased more than the water pressure. Injected grouting quantity per hole and the grout hole lengths were noted as in the Table IV.

4). Grouting termination: During drilling of holes, water was diverted to a channel. After reaching of the maximum pressure and minimum grout flow ( $<1 \mathrm{lit} / \mathrm{min})$, the injection of particular hole was terminated and next grout hole was taken up for injection. In some grout holes the leakage from the jointed rock mass was controlled by increasing volume of polyurethane grout, after few minutes. Injection quantity was found to decrease $(<1 \mathrm{lit} / \mathrm{min})$ with time, consequently, injection pressure was found to increase greater than 10 bar within 2-5 min. The above observation indicated that grout termination of a particular grout hole had reached.

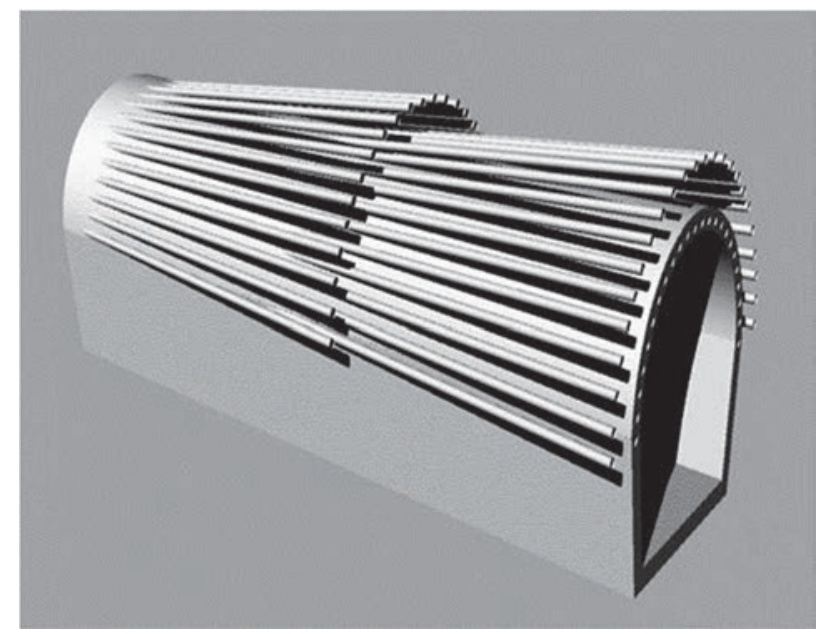

Fig. 8.Polyurethane grouting scheme
4) Second stage pipe roofing: After grouting of first stage, mostly water seepage area was sealed and the seepage was observed to be around $25-30 \mathrm{lit} / \mathrm{min}$ in the tunnel.

TABLE IV. GROUT CONSUMPTION AND INJECTION TIME

\begin{tabular}{|r|r|r|r|r|}
\hline $\begin{array}{l}\text { Grout Hole } \\
\text { No. }\end{array}$ & \multicolumn{1}{c|}{$\begin{array}{c}\text { Part-A } \\
(\mathbf{K g})\end{array}$} & \multicolumn{1}{c|}{$\begin{array}{c}\text { Part-B } \\
(\mathbf{K g})\end{array}$} & \multicolumn{1}{c|}{$\begin{array}{c}\text { Total } \\
\text { Quantity } \\
(\mathbf{k g})\end{array}$} & \multicolumn{1}{c|}{$\begin{array}{c}\text { Time } \\
(\mathbf{m i n})\end{array}$} \\
\hline 1 & 21 & 24 & 45 & 3.0 \\
\hline 2 & 105 & 120 & 225 & 8.3 \\
\hline 4 & 84 & 96 & 180 & 8.3 \\
\hline 5 & 31.5 & 36 & 67.5 & 2.3 \\
\hline 7 & 31.5 & 36 & 67.5 & 3.0 \\
\hline 8 & 273 & 312 & 585 & 40.0 \\
\hline 9 & 0 & 0 & 0 & \\
\hline 10 & 42 & 48 & 90 & 11.0 \\
\hline 11 & 556.5 & 636 & 1192.5 & 60.4 \\
\hline 12 & 115.5 & 132 & 247.5 & 20.0 \\
\hline 13 & 60 & 62 & 122 & 15.0 \\
\hline 14 & 26 & 26 & 52 & 3.0 \\
\hline 16 & 23 & 22 & 45 & 2.5 \\
\hline 20 & 18 & 19 & 37 & 2.5 \\
\hline 22 & 14 & 15 & 29 & 2.0 \\
\hline 23 & 15 & 15 & 30 & 2.0 \\
\hline 24 & 0 & 0 & 0 & \\
\hline Total & 1416 & 1599 & 3015 & 183.3 \\
\hline
\end{tabular}

Further construction of HRT was commenced but installation of recommended additional support (i.e. steel ribs, rock bolts etc.). The pipe roofing was extended further $15.0 \mathrm{~m}$. Thus, umbrella support was created above the spring level as second stage of pipe roofing further head of face. The drill hole location selected in between the first stage holes and the section has overlapped with $5 \mathrm{~m}$. These stages were further extended in weak zones.

Fig. 9 to 14 shown the heavy seepage and rock failure in the tunnel before polyurethane grouting and the process involved during grouting, diverting seepage water by grout holes and the tunnel after completion of polyurethane grouting.

\section{A. Limitations}

As with all materials, Polyurethanes also have limitations. Hydrophobic polymers usually have better chemical resistance. To insure proper cross linking during the reaction, water should be tested to ensure a $\mathrm{pH}$ level of 10 or less. A pH close to neutral (7) produces the most ideally cured polymers. A pH below 7 slows down the reactivity and too far below 7.0 will inhibit the reaction. Higher $\mathrm{pH}$ will increase reactivity up to a $\mathrm{pH} 8-9$, but after that will begin to degrade the quality (the water holding ability) of the cured polymer as the $\mathrm{pH}$ increases. As the $\mathrm{pH}$ climbs above 7 , the same is true for increasing alkalinity up 
to the maximum of 14 . While a water temperature of $50 \mathrm{oF}$ degrees or higher is preferred, the materials have been successfully used with water temperatures near freezing. Below $50^{\circ} \mathrm{F}$ the material will steadily decrease its cure rate as well as its physical characteristics, and once the water begins to crystallize, the resin cannot absorb it and the reaction will not occur [3].

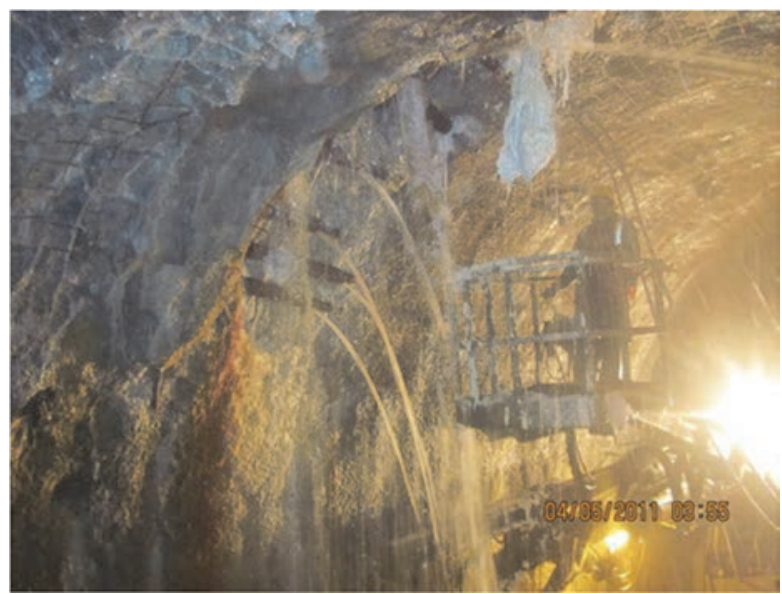

Fig. 9. Diverted water seepage from the tunnel face by drill holes

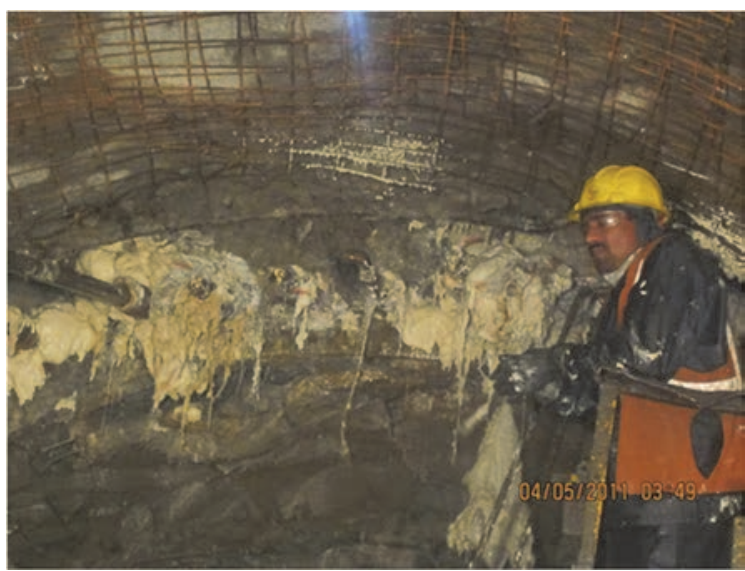

Fig. 10. Pipe roofing arrangements for polyurethane grout

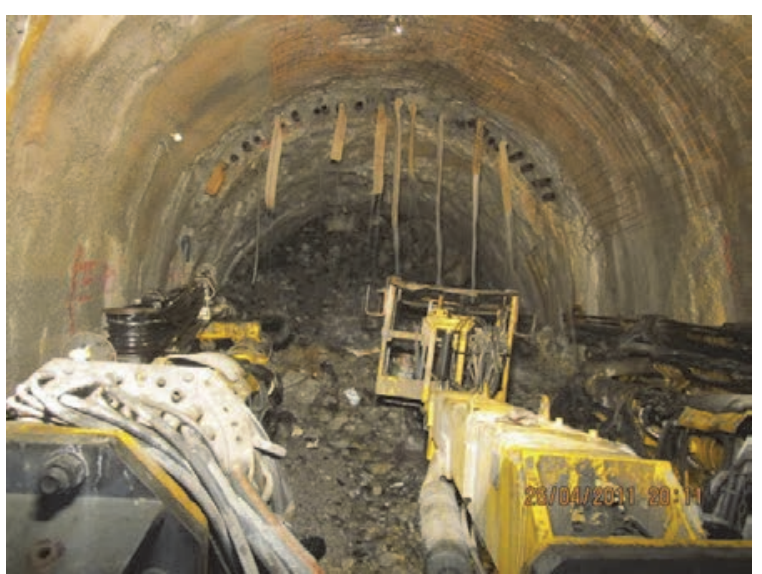

Fig. 11. Packer fixing for polyurethane grout

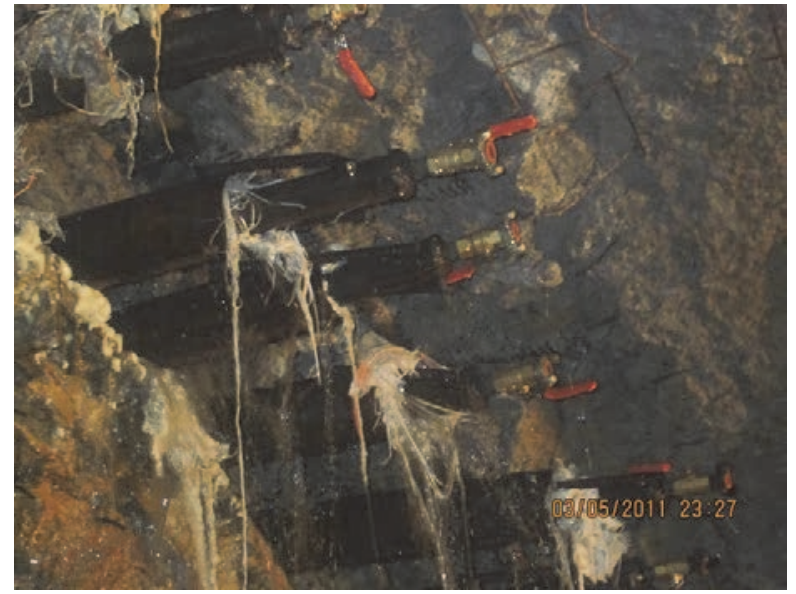

Fig. 12. Polyurethane grouting process

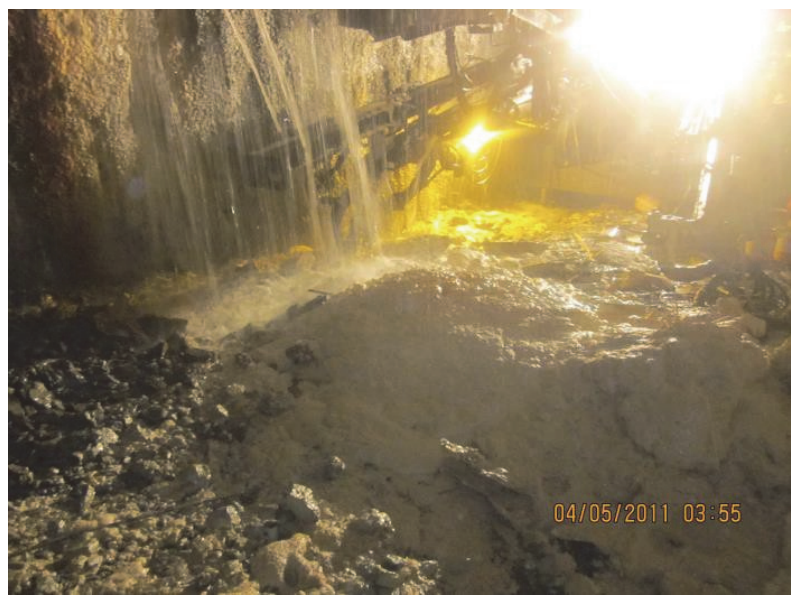

Fig. 13. Tunnel before polyurethane grout

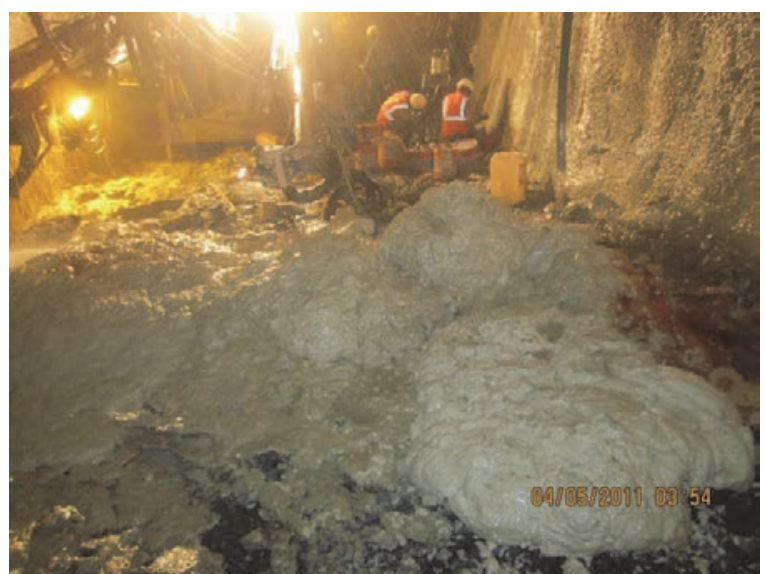

Fig. 14. Tunnel after polyurethane grout

\section{Challanges Encountered During Polyurethane GROUT}

During the injection of polyurethane grout, lots of challenges were encountered. These challenges are listed as under:

- To divert and channelize heavy seepage from face and working with this situation was a challenging task 
- Identification of the water carrying joints and finding exact location of the intersection for grouting

- Drilling of $119 \mathrm{~mm}$ diameter and $15.0 \mathrm{~m}$ holes and inserting pipes simultaneously with drilling in a weak zone.

- Small boulders used to cause difficulty in drilling

- To maintain drill hole deviation

- $\quad$ Packing and sealing of leakage points during injection of grout

- Safety of workers to harmful chemicals for avoid any infection

- Maintain maximum injection pressure, grout volume and flow rate

- During injection some packers and pipes move out with pressure due to high water and injection pressure.

\section{CONCLUSION}

In order to handling heavy seepage in the head race tunnel of the project Tapovan Vishnu gad hydroelectric power project, the crown was treated with polyurethane grout and pipe roofing was employed to stabilize the rock mass above springing level. This task presented numerous challenges. Polyurethane grout is performed in order to seal the leakage and divert the water channels. It also helped in achieving improvement in physical and mechanical properties of the rock and the materials in the cavity. This is a temporary technique for handling the worst situation and installation of permanent rock support were required to complete the stabilsation of the area. The ground water ingress during excavation of the Head Race Tunnel were handled by judicious combination of probing and polyurethane grouting and pipe roofing. The initial seepage water quantity of $1800-2000 \mathrm{lit} / \mathrm{min}$ was controlled to 25-30 lit/min after polyurethane grout. To improve the performance of grouting, experience and complex knowledge from the various field like geology, hydrogeology and structural geology of the area and working experience in underground construction, chemistry of the grouting materials, equipment (pumps, packers) and grouting techniques (injection pressure, injection volume, injection time etc.) are required.

\section{REFERENCES}

[1] "TAM leak sealing brouser," Global Construction Chemicals .

[2] J. Bodi, Z. Bodi, J. Scucka and P. Martinec,"Polyurethane grouting technologies, polyurethane," Dr. Fathmina Zafar (Ed.), InTech, DOI: 10.5772/35791.

[3] D. Magill, and R. Berry, "Comparision of chemical grout properties," Avanti International. 